\title{
JENIS TINDAK TUTUR DALAM KHOTBAH JUMAT DI MASJID SYARQĪ, KAIRO MESIR: KAJIAN PRAGMATIK
}

\author{
Tri Yanti Nurul Hidayati \\ Jurusan Sastra Arab \\ Fakultas Sastra dan Seni Rupa \\ Universitas Sebelas Maret
}

\begin{abstract}
Based on the above, the issues examined in this study is the locution of speech acts, illocution and perlocution in a Friday khotbah by Egyptian native speakers Syeikh Sa idd Ruslan with the theme Baina As-Sürah wa Al-Haqiqah' between picture and reality, on April 25, 2008 in mosque Syarqī in Manüfiyyah province, Subkh Aḥad, Markāz Asymūn village, Cairo, Mesir with a pragmatic analysis. The data are sentences containing locution, illocution and perlocution. The result of analysis shows that speaker of Friday khotbah (khatīib) not only use one speech act, but also use some speech acts, that is locution speech act, illocution speech act and perlocution speech act. Locution speech act is the most widely used in Friday khotbah, because it is only used to declare or inform something. In first and second khotbah, the data of locution speech act is found in opening, content and closing. The data of illocution speech act is found in opening and content, while perlocution speech act is found in closing. Illocution speech act includes Follow-illocutionary in the data message includes assertive (strengthen), directive (prohibiting, commanding), expressive (praise), declaration (testimony), commissive (swear).
\end{abstract}

Keywords: locution speech act, illocution speech act, perlocution speech act, khotbah

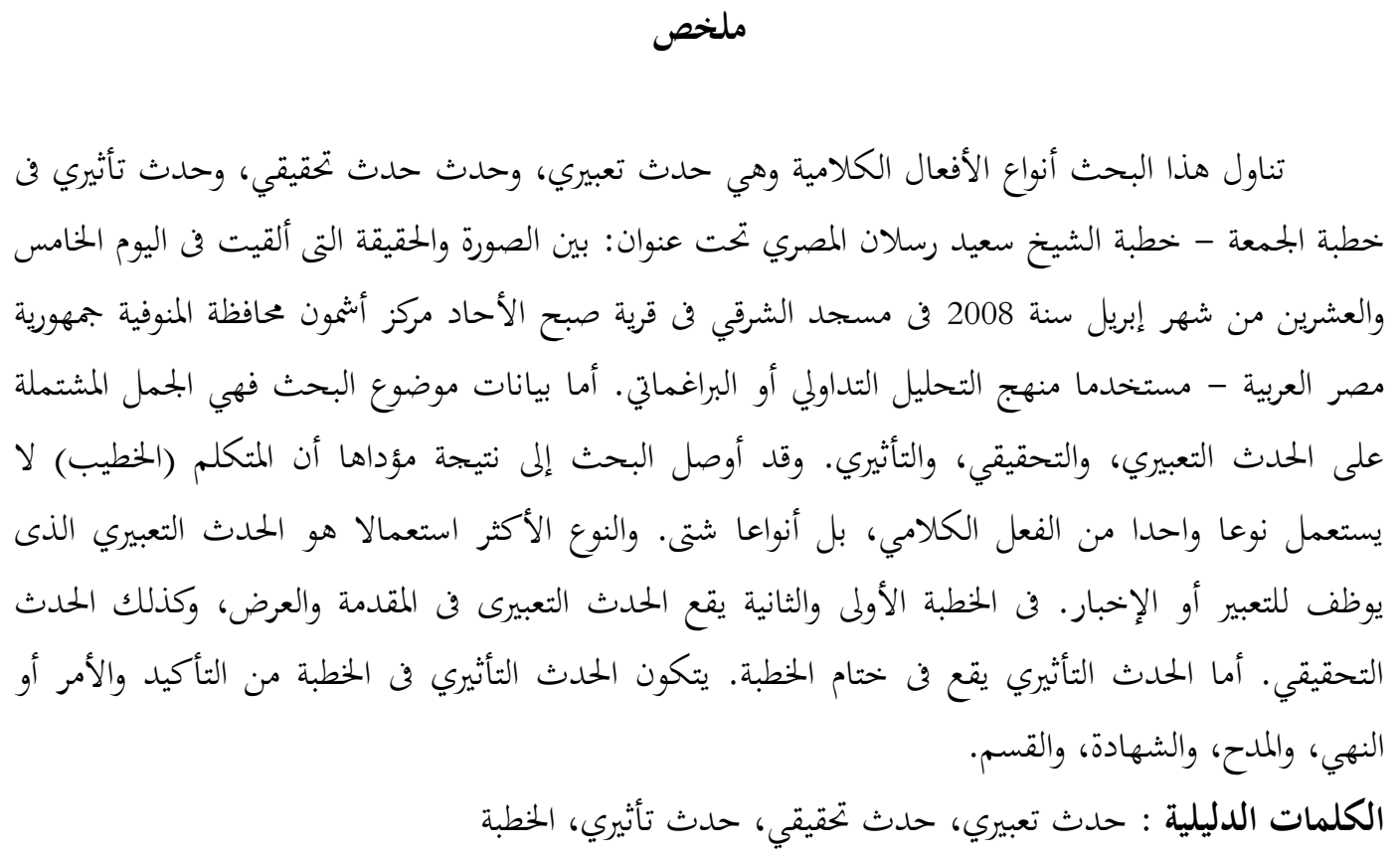




\section{Pendahuluan}

Bahasa sebagai alat komunikasi berfungsi menyampaikan pesan dari penutur (komunikator) kepada mitra tutur (komunikan). Terdapat dua macam komunikasi bahasa yang terjadi antarmanusia dalam masyarakat, yaitu komunikasi searah dan komunikasi dua arah (Chaer, A dan Leoni, 2004:21). Dalam komunikasi searah, penutur (komunikator) tetap sebagai penutur (komunikator), dan mitra tutur (komunikan) tetap sebagai mitra tutur. Komunikasi searah ini terjadi, misalnya, dalam komunikasi yang sifatnya memberitahukan, khotbah di masjid atau gereja, dan ceramah yang tidak diikuti tanya jawab. Dalam komunikasi dua arah, secara berganti-ganti penutur (komunikator) dapat menjadi mitra tutur (komunikan), dan mitra tutur (komunikan) dapat menjadi penutur (komunikator). Komunikasi dua arah ini, misalnya terjadi dalam rapat, perundingan, dan diskusi.

Salah satu komunikasi searah yang menggunakan bahasa adalah khotbah. Khotbah berasal dari bahasa Arab khutbah/alkhitābah, artinya 'pidato' (Munawwir, 1997:349). Khotbah adalah seni pembicaraan kepada khalayak yang di dalamnya terdapat suatu pesan (Abu Soleh dan Ahmad, 1411 H:170). Di dalam khotbah, biasanya penutur (khatīib) menyampaikan ide, gagasan, dan pikirannya kepada mitra tutur (jama'ah). Hakikat khotbah adalah wasiat untuk bertakwa, kepada khalayak baik bentuknya janji kesenangan maupun ancaman kesengsaraan (Sabiq, t.t :291). Khotbah pada umumnya dinamakan berdasarkan konteks situasi, kondisi, dan tempat khotbah tersebut disampaikan. Dengan demikian maka muncullah khotbah Jumat, yaitu khotbah yang disampaikan sebelum pelaksanaan shalat Jumat, khotbah Hari Raya, yaitu khotbah yang disampaikan setelah shalat hari raya Idul Fitri atau Idul Adḥā, serta khotbah-khotbah yang lain. Ar-Rahbawi dalam bukunya Fikih Shalat Empat Madzhab

(2005:320), mengemukakan bahwa khotbah Jumat dilaksanakan pada hari Jumat karena hari Jumat adalah sebaik-baik hari yang di dalamnya terbit matahari. Pada hari Jumat diciptakan Adam 'alaihi as-salām, pada hari itu pula dia dimasukkan ke surga dan pada hari itu juga dia dikeluarkan dari surga, dan hari kiamat pun akan terjadi pada hari Jumat (Ar-Rahbawi, 2005:320). Selain itu, hari Jumat adalah hari paling mulia untuk orang Islam (Az-Zabidi, 2002:233), hari yang paling agung di sisi Allah, dan lebih agung di sisi Allah dari pada hari raya Idul Fitri dan Idul Adhāa (Ar-Rahbawi, 2005:320). Bukhari dalam hadisnya juga menyebutkan bahwa istimewanya hari Jumat, yaitu pada hari tersebut terdapat suatu saat yang apabila tepat pada saat itu seorang muslim berdiri melaksanakan shalat dan memohon sesuatu kepada Allah, niscaya Allah akan memberinya (Az-Zabidi, 2002: 244). Muslim dalam hadisnya yang berkenaan dengan keistimewaan hari Jumat, menyebutkan bahwa waktu terkabulnya doa pada hari Jumat, yaitu antara duduknya imam hingga selesai salat (AlMundziri, 2003:231).

Dalam khotbah Jumat, penutur (khatīb) menyampaikan khotbahnya menggunakan tuturan. Tuturan adalah produk suatu tindak tutur (Leech, 1993: 20). Adapun isi tuturan yang ada dalam khotbah tidak lain merupakan ajakan penutur (khatīib) terhadap mitra tutur (jama'ah) nya untuk menjadi orang yang bertakwa. Seorang khatīb harus mampu membuat jama'ah tertarik dengan isi khotbahnya. Oleh karena itu, seorang khat $\bar{i} b$ harus dapat menggunakan bahasa yang tepat agar jama' ah tertarik dengan isi khotbah yang disampaikan.

Pemilihan khotbah Jumat oleh penutur asli Mesir sebagai objek penelitian dianggap penting dan menarik karena sejauh pengamatan penulis dalam khotbah tersebut khatīb menyampaikan ide, pikiran, serta amanat menggunakan bahasa Arab dengan semangat yang berapi-api. Hal ini terlihat ketika khatīb 
menyampaikan isi khotbah tentang Baina As-sürah wa Al-Haqiquah 'antara gambar dan kenyataan'. Hampir semua isi khotbah tersebut di sampaikan penutur (khatīib) dengan suara keras dan berapi-api, terlebih lagi apabila pembahasannya yang berkaitan dengan ayat-ayat al-Quran yang berisi peringatan dari Allah tentang balasan dari dosa dan maksiat yang dilakukan manusia. Hal ini sesuai dengan Nabi ketika berkhotbah. Dalam suatu riwayat, disebutkan bahwa Nabi SAW apabila berkhotbah, kedua matanya memerah, suaranya meninggi, dan semangatnya memuncak. Beliau bagaikan panglima perang yang sedang memberi peringatan kepada pasukannya (Bin Thahir, 2008: 21). Berbeda halnya dengan khotbah yang ada di Indonesia. Di Indonesia, khatīb menyampaikan khotbahnya dengan bahasa yang lebih halus. Hal ini tidak terlepas dari kondisi geografis letak negara tersebut. Sebagian besar daratan Mesir merupakan gurun Sahara yang jarang dihuni. Di Indonesia, dikenal dengan negara timur yang dikelilingi beberapa samudera. Berdasarkan perbedaan segi geografis inilah, tipe dan watak manusianya pun berbeda.

Khotbah Jumat oleh penutur asli Mesir dengan menggunakan bahasa Arab, misalnya tampak pada khotbah Jumat yang disampaikan oleh Syeikh Sa idd Ruslan pada tanggal 25 April 2008 di masjid Syarqi $\bar{i}$ tepatnya di propinsi Manüfiyyah, desa Subkh Ahad, Markāz Asymūn, Kairo, Mesir. Khotbah ini menggunakan bahasa Arab secara keseluruhan, karena disesuaikan dengan masyarakat Mesir yang bahasa nasionalnya adalah bahasa Arab. Selain itu, agar maksud yang disampaikan oleh khatib dapat dipahami oleh pendengar dalam khotbah tersebut, karena apabila maksud khatīb tersebut tidak dapat ditangkap oleh pendengar khotbah maka hakikat dari khotbah, yaitu wasiat atau wejangan yang isinya mengajak untuk bertakwa, tidak ada.
Penulis memilih pembahasan khotbah Jumat karena hari Jumat merupakan momentum berkumpulnya manusia dan khotbah dilaksanakan sebelum melaksanakan salat Jumat, sehingga lebih efektif untuk memberi wasiat atau nasehat. Selain itu, khotbah Jumat merupakan salah satu metode dakwah yang paling menonjol dan paling dikenal sebagai pintu dakwah yang sangat luas dan sarana dakwah yang paling besar dalam menyampaikan dan menyebarkan Islam di tengah umat manusia. Selanjutnya, penulis memilih menggunakan analisis pragmatik khususnya pembahasan tindak tutur, karena penulis ingin mengetahui jenis tindak tutur dalam khotbah Jumat yang disampaikan oleh penutur asli Mesir.

\section{Khotbah dan Pragmatik}

\subsection{Khotbah}

Kata khotbah berasal dari bahasa Arab khutbah, artinya 'pidato' (Munawwir, 1997:349). Khotbah sudah ada sejak masa jahiliyah dan ketika Islam sudah muncul, Rasulullah bersama para sahabatnya berdakwah untuk menyampaikan ajaran-ajaran Islam, dengan memulai dari menyampaikan salah satu dari syair-syair Islam. Kemudian dakwah Rasul dan sahabat tersebut berkaitan dengan shalat Jumat, shalat ' $T d$, shalat Istisqa, yang sesuai dengan permasalah pada waktu itu. Penutur (khatīb) berdiri di depan manusia untuk berbicara tentang permasalahan agama (akherat) dan dunia. Bermula dari kebiasaan itulah, dakwah menjadi bagian dari kehidupan keseharian kaum muslimin dan dari situ pula khotbah mulai menyebar dan beragam bentuknya (Abu Soleh dan Ahmad, 1411H:170). Khotbah adalah seni pembicaraan kepada khalayak yang di dalamnya terdapat suatu pesan (Abu Soleh dan Ahmad, 1411H:170). Hakikat khotbah itu sendiri adalah wasiat untuk bertakwa kepada khalayak baik bentuknya janji kesenangan maupun ancaman kesengsaraan (Sabiq, t.t. : 291). Ragam khotbah pun bermacam-macam dan 
disesuaikan dengan tema pada saat itu (Abu Soleh dan Ahmad, 1411 H:171). Apabila berkaitan dengan tema urusan agama dan keyakinan disebut khotbah agama, berkaitan dengan sosial kemasyarakatan dan perjanjian perdamaian disebut khotbah sosial, barkaitan dengan politik disebut khotbah politik, berkaitan dengan pernikahan disebut khotbah nikah. Begitu pula khotbah Jumat, yaitu khotbah yang disampaikan sebelum shalat Jumat. Khotbah Jumat itu hukumnya wajib (Sabiq, tt. : 289), Artinya, seandainya khotbah itu ditiadakan, maka shalat Jumat tidak sah (Sabiq, tt :362). Di samping itu, khotbah Jumat ditujukan untuk jamaah pada umumnya yang hadir pada rangkaian ibadah Jumat tersebut. Khotbah Jumat berbeda dengan khotbah hari raya, khotbah gerhana dan khotbah Istisqa. Khotbah Jumat ini disampaikan sebelum shalat Jumat, sedangkan khotbah hari raya, khotbah gerhana, dan khotbah istisqa disampaikan setelah shalat ditunaikan.

Khotbah Jumat memiliki dua bagian khotbah, yakni khotbah pertama dan khotbah kedua (Sabiq, t.t. :291). Struktur khotbah pertama dan kedua terdiri dari pembukaan (bagian awal), isi (bagian tubuh), dan penutup (bagian akhir). Dalam pembukaan (bagian awal), khatīb menyampaikan kalimat pengantar sebelum masuk dalam pembahasan (gagasan, ide) khotbah. Sesuai petunjuk nabi, pada bagian awal beliau memulai dengan (1) membaca hamdallah (2) membaca syahadat (3) membaca salawat dan salām (4) dan perkataan ammā ba'du (Bin Thahir, 2008:47). Bagian isi sebagai pemaparan gagasan, ide atau isi khotbah yang berupa nasehat atau wejangan. Adapun bagian penutup sebagai penanda akhir khotbah yang biasanya berisi kesimpulan dari pembahasan (gagasan, ide) diikuti dengan doa, permohonan ampun kepada Allah dan salam yang dipanjatkan oleh penutur (khatīb). Dalam khotbah terdapat beberapa syarat yang apabila salah satunya ditinggalkan, maka khotbahnya tidak sah, sehingga shalat
Jumatnya pun tidak sah. (Ar-Rahbawi, 2008: 328-331). Syarat-syarat tersebut adalah: (1) khotbah dikerjakan sebelum shalat Jumat; (2) niat, bila khotbah dilakukan tanpa niat maka khotbah tersebut tidak sah; (3) dengan bahasa Arab. Apabila tidak mampu dengan bahasa Arab, maka disyaratkan ketika membaca ayat saja yang menggunakan bahasa Arab, kecuali ulama Malikiyyah, menurut beliau menggunakan bahasa Arab adalah syarat mutlak meskipun orang-orang tidak mengetahui bahasa Arab. Apabila tidak ada orang yang dapat berbahasa Arab dengan baik, maka gugurlah kewajiban shalat Jumat bagi mereka. Sementara menurut ulama Hanafiyyah, khotbah boleh dilaksanakan dengan menggunakan bahasa selain bahasa Arab meskipun sang khatīb mampu berbahasa Arab, baik masyarakatnya orang Arab maupun selain Arab; (4) khotbahnya dilakukan pada waktunya. Artinya, tidak sah jika khotbahnya dikerjakan sebelum masuk waktu shalat Jumat dan baru shalatnya yang dikerjakan ketika sudah masuk waktu shalat; (5) kedua khotbahnya diucapkan dengan suara keras sekira para jama'ah yang mengikuti shalat Jumat dapat mendengarnya. Hal ini sesuai hadis riwayat Muslim dan Nasa ‘ yang menyebutkan bahwa ketika Rasulullah SAW berkhotbah, maka wajahnya memerah, suaranya meninggi, dan emosinya memuncak seolah sedang memberikan instruksi kepada pasukan; (6) antara khotbah pertama dan kedua dilakukan berturut-turut, begitu pula antara khotbah dan shalat, yaitu tidak menyelingi antara khotbah pertama, kedua, dan shalat dengan yang lainnya; (7) penyampaian kedua khotbah tersebut dengan berdiri jika sanggup. Bila tidak sanggup, maka sah disampaikan sambil duduk, kecuali ulama Hanafiyyah dan Hanbaliyyah, dalam pandangan mereka, berdiri dalam khotbah adalah sunnah bukan farcu;(8) duduk di antara dua khotbah sekira diam sejenak (tumaninah). Meskipun khotbahnya disampaikan sambil duduk karena ada 
halangan ('użur), maka di antara dua khotbah tersebut khatib harus diam sejenak. Pendapat ini hanya menurut ulama Syafi iyyah. Adapun menurut ulama yang bukan Syafi iyyah duduk di antara dua khotbah adalah sunah. Lamanya duduk di antara dua khotbah ini, seukuran dengan duduk sejenak ketika salat (yaitu sebelum bangkit untuk melanjutkan rekaat berikutnya), dan seukuran lamanya membaca surat al-Ikhlas. Hikmah dari duduk di antara khotbah ini, yaitu memisahkan antara khotbah pertama dan kedua. Menurut ulama selain Syafi iyyah, hikmahnya adalah untuk istirahat (Bin Thahir, 2008: 35); (9) khat $\bar{i} b$ suci dari hadas dan menutup aurat dalam kedua khotbahnya. Seandainya khatīb berhadas di tengah-tengah khotbahnya, maka dia harus menghentikan khotbahnya dan dilanjutkan setelah memperbaharui wudhunya terlebih dahulu. Pendapat ini adalah menurut Syafi iyyah, sedangkan menurut ulama selainnya, suci dari hadas adalah sunah bagi khatīb; (10) khatīib adalah orang yang berkewajiban shalat Jumat. Dengan demikian, khati $\bar{i}$ tidak boleh seorang budak atau musafir, meskipun dia telah meniatkan untuk menghentikan masanya sebagai musafir. Pendapat ini hanya menurut ulama Hanbaliyyah. Dalam hal ini, ulama selainnya sepakat sebatas bila jumlah minimal yang menjadi syarat shalat Jumat hanya terpenuhi bila sang khatíb sendiri masuk hitungan. Adapun jika jumlah minimal sudah terpenuhi walaupun tanpa menghitung khat $\bar{i} b$, maka tidak ada syarat bahwa khatīb harus orang yang berkewajiban shalat Jumat.

Dalam khotbah terdapat beberapa rukun. Dalam hal ini terjadi banyak perbedaan pendapat di antara para ulama. Ulama Hanafiyyah, Malikiyyah mengatakan bahwa rukun khotbah hanya satu dan selainnya sunah (Ar-Rahbawi, 2008: 331). Berikut ini rukun-rukun khotbah: (1) memuji Allah. Memuji tersebut dengan kalimat Al-hamdulillah. Ulama Hanafiyyah mengatakan bahwa rukun khotbah hanya satu, yaitu żikr dalam segala bentuknya, bisa dalam bentuk tahmid, tasbihh, atau tahlill. Hanya saja makruh hukumnya jika menyebutnya dengan sangat ringkas. Hal ini berdasarkan firman Allah SWT QS al-Jumu'ah ayat 9 yang berbunyi

$$
\text { فاسْعِو الي ذكُر الله وذرُ الْبْيْع }
$$

“...maka segeralah mengingat Allah dan tinggalkanlah jual beli”.

$\dot{Z} i k r$ yang dimaksud dalam ayat tersebut adalah khotbah, dan rukun selain żikr adalah sunah. Ulama Malikiyyah berpendapat bahwa membaca hamdalah adalah rukun khotbah yang mencakup kabar gembira atau peringatan, dan selain itu adalah sunah. Dengan demikian, rukun yang disebutkan di atas adalah pandangan ulama Syafi iyyah dan Hanbaliyyah; (2) berșalawat kepada Nabi Muhammad SAW dalam dua khotbahnya. Hal ini berdasarkan firman Allah dalam Al-quran surat al-Ahzab ayat 56 yang artinya:"Hai orang-orang yang beriman, bershalawatlah kamu untuk Nabi dan ucapkanlah salam dengan penuh penghormatan kepadanya"; (3) berwasiat dengan takwa pada kedua khotbah meskipun tanpa menyebut secara eksplisit kata 'wasiat takwa'. Artinya dipandang cukup dengan menyebut 'taatlah kepada Allah', sebab inilah maksud utama dalam khotbah itu sendiri; (4) membaca ayat Al-Quran dalam salah satu dari dua khotbah, dan membacanya pada khotbah pertama lebih baik; (5) mendoakan kaum mukminin dan mukminat, khususnya pada khotbah kedua. Pendapat ini hanya menurut ulama Syafi iyyah saja. Ulama Syafi iyyah berpegang pada riwayat dari Samurah bin Jundub, yang menyatakan bahwa Nabi SAW memohonkan ampun bagi kaum mukminin dan mukminat dalam setiap shalat Jumat.

Dalam khotbah terdapat sunahsunah khotbah (Ar-Rahbawi, 2008: 334). Adapun sunah-sunah khotbah adalah sebagai berikut: (1) mengucapkan salām 
ketika baru naik mimbar, kecuali ulama Hanafiyyah yang mengatakan bahwa hal itu tidak disunahkan; (2) duduk di atas mimbar dan sejenisnya sebelum khotbah, serta menghadapkan wajah ke arah jama'ah. Kata mimbar المنبر al-minbaru 'mimbar' berasal dari kata ungkapan نبر الثّيء nabara as-syaia 'mengangkat atau meninggikan sesuatu'. Ia dinamakan mimbar karena letaknya yang tinggi (Bin Thahir, 2004:12). Mimbar Rasulullah Saw terdiri dari tiga tingkat. Beliau berkhotbah pada tingkat yang kedua dan duduk pada tingkat yang ketiga (Bin Thahir, 2004:17); (3) khotbah dilakukan di atas mimbar atau tempat yang tinggi agar dapat didengar orang; (4) tangan kirinya memegang pedang atau tongkat; (5) ażan di hadapan khati ib; (6) membaca dua kalimat syahadat dalam khotbah; (7) khotbah pertama lebih panjang daripada khotbah kedua dan hendaknya disampaikan dengan bahasa yang mudah dimengerti.

Hal-hal yang makruh dalam khotbah adalah sengaja meninggalkan sunah-sunah yang telah disebutkan sebelumnya, membelakangi jama'ah, dan mengangkat tangan ketika berdoa (Ar-Rahbawi, 2008:335)

Beberapa kesalahan yang dilakukan khat $\bar{i} b$ dalam khotbah Jumat antara lain (bin Thahir, 2008: 60-65): emperpanjang khotbah namun mempercepat salat; (2) mudah menyebutkan hadis-hadis yang lemah dan munkar; (3) menyebutkan orang tertentu secara jelas; (4) membicarakan tema-tema yang dapat menimbulkan fitnah, seperti pembicaraan tentang politik; (5) mengangkat kedua tangan (ketika berdoa) di tengah-tengah khotbah; (6) selalu membaca $\dot{z} i k r-z i k r$ atau doa-doa tertentu seolah-olah hal tersebut disunahkan; (7) Ssengaja menghadirkan salawat dan salām kepada nabi SAW. Misalnya, khatīb memerintahkan jamaah yang hadir untuk bersalawat ketika khatīb menyebut nama Rasulullah SAW; (8) merutinkan doa bagi orang-orang tertentu pada setiap khotbah Jumat, sehingga seakan-akan perbuatan itu sunnah; (9) sengaja membaca șalawat dan salām untuk sahabat Nabi SAW; (9) nengharuskan pakaian tertentu sehingga ia terkesan sebagai sebuah sunnah. Misalnya, keharusan memakai jubah hitam; (10) para khat $\bar{i} b$ mengatakan apa yang tidak mereka lakukan; (11) sebagian khatīb hanya memperhatikan kefasihan bahasa, sastra yang tinggi, dan penyampaian dengan isak tangis, sementara dalam waktu yang sama mereka tidak memberi perhatian yang baik untuk memperdalam ilmu agama dan terus mempelajarinya; (12) berdoa dengan bersenandung, memanjangkan suara, dan bersajak.

\subsection{Pragmatik}

Pragmatik merupakan cabang ilmu bahasa yang mempelajari struktur bahasa secara eksternal. Semakin dikenal pada masa sekarang ini walaupun pada kira-kira dua dasawarsa yang silam ilmu ini hampir jarang atau tidak pernah disebut oleh para ahli bahasa. Hal ini dilandasi oleh semakin sadarnya para linguis bahwa upaya menguak hakikat bahasa tidak akan membawa hasil yang diharapkan tanpa didasari pemahaman terhadap pragmatik, yakni bagaimana bahasa itu digunakan dalam komunikasi (Wijana, 1996:46).

Leech (1993:8) memberikan definisi pragmatik sebagai studi tentang makna dalam hubungannya dengan situasi-situasi ujar (speech situation). Fenomena dalam kajian pragmatik mencakup tindak tutur, deiksis, presuposisi (Inggris: pressuposition), dan implikatur percakapan (Inggris: conversation alimpticatre) (Chaer, A dan Leoni, 2004:56). Adapun dalam penelitian ini, hal yang akan dibahas adalah tindak tutur. Tindak tutur adalah tindakan-tindakan yang ditampilkan lewat tuturan (Yule, 1996:82). Tindak tutur merupakan gejala individual, bersifat psikologis, dan keberlangsungannya ditentukan oleh kemampuan bahasa si penutur dalam menghadapi situasi tutur. Kalau dalam peristiwa tutur lebih dilihat pada tujuan peristiwanya, tetapi dalam tindak tutur 
lebih dilihat dalam makna atau arti tindakan dalam tuturannya (Chaer, A dan Leoni, 2004:50). Sebelum membahas teori mengenai tindak tutur, akan dibahas tentang pembagian jenis kalimat yang dilakukan oleh para tata bahasa tradisional. Menurut tata bahasa tradisional, terdapat tiga jenis kalimat, yaitu (1) kalimat deklaratif, (2) kalimat interogatif, dan (3) kalimat imperatif (Chaer, A dan Leoni, 2004: 50). Kalimat deklaratif adalah kalimat yang isinya hanya meminta pendengar atau yang mendengar kalimat itu untuk menaruh perhatian saja, tidak perlu melakukan sesuatu. Dengan kata lain kalimat deklaratif adalah kalimat yang diucapkan hanya untuk memberitahukan saja. Kalimat interogatif adalah kalimat yang isinya meminta agar pendengar atau orang yang mendengar kalimat itu untuk memberi jawaban secara lisan. Dengan kata lain, kalimat interogatif adalah kalimat yang isinya tidak hanya sekadar perhatian, melainkan juga jawaban. Adapun kalimat imperatif adalah kalimat yang isinya meminta agar si pendengar atau yang mendengar kalimat itu memberi tanggapan berupa tindakan atau perbuatan yang diminta.

Tindak tutur secara pragmatis dapat diwujudkan oleh penutur melalui tiga jenis tindak tutur, yaitu tindak lokusi (locutionary act), tindak ilokusi (ilocutionary act), dan tindak perlokusi (perlocutionary act) (Wijana, 1996:17).

a. Tindak lokusi adalah tindak tutur untuk menyatakan sesuatu (Wijana, 1996:17). Tindak tutur ini disebut The Act of Saying Something. Tuturan atau kalimat dalam hal ini dipandang sebagai satu satuan yang terdiri dari dua unsur, yakni subjek/topik dan predikat/comment (Nababan, 1987:4). Konsep lokusi adalah konsep yang berkaitan dengan proposisi kalimat (Wijana, 1996:4).

b. Tindak ilokusi adalah tuturan yang memiliki fungsi selain untuk mengatakan atau menginformasikan sesuatu, dapat juga dipergunakan untuk melakukan sesuatu (Wijana, 1996:18). Tindak ilokusi ini disebut sebagai The Act of Doing Something.

c. Tindak perlokusi adalah sebuah tuturan yang diutarakan oleh seseorang yang seringkali mempunyai daya pengaruh (perlocutionary force), atau efek bagi yang mendengarkannya (Wijana, 1996:19). Efek atau daya pengaruh ini dapat secara tidak sengaja dikreasikan oleh penuturnya.

Tindak tutur sebenarnya merupakan salah satu fenomena dalam masalah yang lebih luas, yaitu pragmatik. Berdasarkan pembagian jenis tindak tutur di atas, dapat kita amati bahwa dalam pragmatik, tuturan tidak hanya berfungsi untuk menyatakan atau menginformasikan sesuatu (fungsi lokusi), tetapi dengan tuturan, penutur dapat melakukan sesuatu (fungsi ilokusi) dan dengan tuturan pula penutur dapat mempengaruhi mitra tutur (fungsi perlokusi). Dalam ilmu bahasa, tindak lokusi dapat disamakan dengan 'predikasi', tindak ilokusi dapat disamakan dengan 'maksud kalimat', dan tindak perlokusi dapat disamakan dengan 'akibat suatu ungkapan' (Lubis, 1993:9).

\section{Pembahasan}

Dalam bab penelitian akan dibahas jenis tindak tutur dalam khotbah Jumat yang disampaikan oleh Syeikh Sa id Ruslan di masjid Syarqi, pada tanggal 25 April 2008.

Sebagaimana tersebut pembahasan sebelumnya, Searle membagi tindak tutur menjadi tiga, yaitu tindak tutur lokusi (locutionary act), tindak tutur ilokusi (illocutionary act) dan tindak tutur perlokusi (perlocutionary act). Jenis tindak tutur tersebut akan dijadikan pijakan dalam analisis bab ini. Berdasarkan data khotbah Jumat yang didapat, penulis menemukan 118 tindak tutur lokusi, 62 tindak tutur ilokusi, dan 2 tindak tutur perlokusi. Pada khotbah pertama dan kedua dalam khotbah Jumat penulis menemukan tindak tutur lokusi terdapat pada bagian pembukaan, isi, dan penutup, tindak tutur ilokusi pada bagian 
pembukaan dan isi sedangkan tindak tutur perlokusi terdapat di penutup khotbah. Berdasarkan data tersebut peneliti hanya mengambil 10 data lokusi, 11 data ilokusi dan 1 data perlokusi untuk dijadikan bahan analisis. Pengambilan sampel data yang hanya beberapa saja untuk dijadikan bahan analisis, karena contoh data tersebut dianggap mewakili masingmasing jenis tindak tutur lokusi, ilokusi dan perlokusi. Selain itu, keterbatasan waktu dan tenaga penulis untuk menganalisis semua data yang ada dalam khotbah Jumat.

\subsection{Tindak Lokusi}

Tindak lokusi adalah tindak tutur untuk menyatakan sesuatu (Wijana, 1996:17), dan biasanya dipandang kurang penting dalam kajian tindak tutur (Nadar, 2009:14). Tindak lokusi diutarakan oleh penuturnya semata-mata untuk menginformasikan sesuatu tanpa tendensi untuk melakukan sesuatu, apalagi untuk mempengaruhi lawan tuturnya (Wijana, 1996:18). Konsep lokusi berkaitan dengan proposisi kalimat. Proposisi adalah konfigurasi makna yang menjelaskan isi komunikasi dari pembicara (Kridalaksana, 2009:20). Proposisi ini biasanya berhubungan dengan arti harfiah dasar dari suatu klausa sederhana (Yule, 1996:10). Tuturan dalam hal ini dipandang sebagai satu kesatuan yang terdiri dari subjek dan predikat (Nababan, 1987:4). Pengidentifikasian dapat dilakukan tanpa menyertakan konteks tuturan yang tercakup dalam situasi tutur (Wijana, 1996:18). Sehingga dapat kita simpulkan, bahwa pengidentifikasian tindak tutur lokusi dapat dilakukan dalam bentuk kalimat yang bermakna dan dapat dipahami.

Kalimat yang menggunakan tindak lokusi dalam khotbah Jumat tersebut antara lain:

Contoh (1)

$$
\text { نفس الفأرية تسعى الهلاك ولإففساد }
$$

'Nafsu tikus berpotensi

menghancurkan dan merusakkan'

(Ruslan, 2008:5).

Contoh (1) merupakan bagian dari isi khotbah Jumat di masjid Syarq $\bar{i}$, Kairo Mesir. Dilihat dari bentuknya, kalimat tersebut termasuk tindak lokusi karena hanya menyatakan sesuatu. Tuturan pada contoh data (1) tersusun dari satu kesatuan yang terdiri dari dua unsur yaitu subjek/topik dan predikat. Dalam bahasa Arab, kalimat tersebut termasuk jumlah ismiyyah yaitu kalimat yang susunannya diawali oleh yang bukan verba 'kata kerja'. Jumlah ismiyyah terdiri dari subjek, yang dalam bahasa Arab disebut dengan mubtada dan predikat, yang dalam bahasa Arab disebut dengan khabar. Mubtada kalimat tersebut adalah نفس الفأرية nafsu alfariyyah 'nafsu tikus' sedang khabarnya adalah تسعى الهلاك ولإفيساد tas 'áal-halāk wa lil-ifsād 'berpotensi menghancurkan dan merusakkan'. Jika dilihat dari proposisinya, contoh (1) memiliki arti harfiah dasar, yaitu nafsu tikus berpotensi menghancurkan dan merusakkan. Pada Contoh (1) susunan kalimatnya tidak mengandung fi' $1 \mathrm{amr}$ 'verba imperatif', $f i^{\prime} l$ nahyi 'kata kerja larangan', ataupun harf taukid 'verba imperfek', sehingga contoh (1) dapat dikatakan sebagai kalimat deklaratif karena hanya memberikan informasi dari penutur (khatīb) kepada mitra tutur (jama'ah). Informasi yang disampaikan yaitu bagaimana dampak nafsu kebinatangan yaitu nafsu tikus yang ada pada diri seseorang. Berdasarkan analisis di atas, dapat diketahui bahwa contoh (1) termasuk tindak tutur lokusi, karena konsep dari lokusi sendiri adalah semata-mata untuk menginformasikan sesuatu tanpa tendensi untuk melakukan sesuatu, apalagi untuk mempengaruhi lawan tuturnya (Wijana, 1996:18).

Contoh (2) 
أبوء لك بنعمتك علي وأبوء بذنبي. أبوء يعني أقر

أعترف

'Aku mengakui nikmat-Mu kepadaku dan mengakui dosa-dosaku. $\underline{\mathrm{Aku} \text { mengakui }}$ yaitu aku menyatakan, aku mengetahui...(Ruslan, 2008: 1)

Contoh (2) di atas termasuk bagian isi khotbah Jumat. Contoh (2) yang bergaris bawah, penutur (khatīb) menyatakan kepada mitra tutur (jama'ah) tentang definisi أبوء $a b u \underline{\text { L } u}$ 'aku mengakui', yaitu 'aku menyatakan', 'aku mengetahui'. Contoh (2) dalam bahasa Arab termasuk jumlah fi'liyah, yaitu kalimat yang diawali oleh $f i^{\prime} l$ 'kata kerja/predikat'. Fi'l pada contoh (2) yaitu أبوء $a b \bar{u}_{\vee} u$ 'aku mengakui'. أبوء $a b \bar{u}_{v} u$ berasal dari kata باءَ $b \bar{a}_{\imath} a$ 'mengakui', sedangkan fa'il 'pelaku/subjek' berupa damīr mustatîr taqdiruhu anā 'kata ganti yang tersimpan menempati arti dari kedudukan saya'. Pada contoh (2) penutur (khatīib) sekedar menyatakan kepada mitra tutur tentang apa itu أبوء abüu 'aku mengakui'. Pernyataan yang didapat mitra tutur dari penutur tersebut tidak mempengaruhi untuk melakukan sesuatu. Melakukan sesuatu di sini maksudnya pembuktian atau penelitian tentang أبوء $a b \bar{u} u$ 'aku mengakui'. Selain itu, untuk mempertegas bahwa contoh (2) termasuk يعني sebuah pernyataan, yaitu adanya kata ya 'ni yang artinya'yaitu'. Kata يعني ya 'ni 'yaitu' pada contoh (2) memberikan pernyataan tentang definisi أبوء $a b \bar{~} u$ ' 'aku mengakui'. Dalam susunan contoh (2) tersebut juga tidak ditemukan verba imperatif maupun larangan. Berdasarkan analisis di atas, dapat diketahui bahwa contoh (2) termasuk tindak tutur lokusi.

Contoh (3)

$$
\begin{aligned}
& \text { كأهل الرياء الذين يعملون لأجل الناس ولا يعملون } \\
& \text { لأجل رب الناس جل وعلا }
\end{aligned}
$$

$$
\text { وهؤلاء عملهم مردود }
$$

'Seperti pelaku riya' yang mereka mengerjakan perbuatan karena manusia dan tidak mengerjakan perbuatan karena Rabb manusia yang agung dan tinggi sehingga amal mereka tertolak'. (Ruslan, 2008:3).

Contoh (3) adalah bagian isi dari khotbah Jumat yang dituturkan penutur (khatib) kepada mitra tutur (jama'ah). Bentuk contoh (3) tersebut jika dilihat dari strukturnya terdiri dari subjek dan predikat. Subjeknya yaitu ahli ar-riy $\bar{a}_{\downarrow} i$ 'pelaku riya', sedang predikatnya yaitu ya'malūna li ajli an-nāsi wa là ya'malūna li ajli Rabbi an-nāsi jalla wa'ala wa hă ulā $i$ mardūdun 'yang mereka mengerjakan perbuatan karena manusia dan tidak mengerjakan perbuatan karena Rabb manusia yang agung dan tinggi sehingga amal mereka tertolak. Contoh (3) dalam bahasa Arab termasuk jumlah ismiyah. Jumlah ismiyah adalah kalimat yang dimulai dari yang bukan verba 'kata kerja'. Subjek dalam jumlah ismiyah disebut mubtada sedangkan predikat disebut dengan khabar. Mubtada pada contoh (3) yaitu الرياء أهل ahli ar-riyās i 'ahli riya', sedang khabarnya yaitu

$$
\begin{aligned}
& \text { يعملون لأجل الناس ولا يعملون لأجل رب الناس جل } \\
& \text { وعلا وهؤلاء عملهم مردود }
\end{aligned}
$$

ya'malūna li ajli an-nāsi wa là ya'malūna li ajli Rabbi an-nāsi jalla wa 'ala wa hă ulā i mardūdun 'mereka mengerjakan perbuatan karena manusia dan tidak mengerjakan perbuatan karena Rabb manusia yang agung dan tinggi sehingga amal mereka tertolak'.

Contoh (3) termasuk kalimat deklaratif, yaitu kalimat yang menyatakan sesuatu. Penutur (khatiib) menyatakan tentang ciri-ciri pelaku riya' yaitu mengerjakan perbuatan karena manusia, bukan karena Tuhan, sehingga perbuatan tersebut tidak diterima oleh Tuhan. Al- 
Gazali dalam bukunya yang berjudul 40 Prinsip Dasar Agama (2000:219-221), menjelaskan bahwa hakikat riya', adalah mencari kedudukan di hati orang banyak dengan melakukan ibadah dan amal-amal baik. Riya' tersebut hukumnya haram dan termasuk dosa besar. Adapun mencari kedudukan di hati banyak orang dengan perbuatan-perbuatan yang bukan termasuk ibadah dan amalan agama, maka tidaklah haram, selama tidak ada penipuan (alGazali, 2000:219-221). Contoh termasuk tindak tutur lokusi, karena penutur (khatiib) hanya menyatakan sesuatu kepada mitra tutur (jama'ah) tanpa adanya efek kepada mitra tutur untuk melakukan seperti yang diinginkan penutur (khatīb). Hal ini juga terlihat dari susunan kata yang membentuk kalimat tersebut. Dalam contoh (3) tersebut tidak terdapat susunan kata yang menyatakan larangan maupun perintah. Adapun harf 'huruf' $\vee$ la 'tidak' yang terdapat dalam contoh (3) dalam bahasa Arab termasuk fi'l manfiy (negative verb) 'verba peniadaan'. Verba peniadaan maksudnya kata kerja yang meniadakan atau mengingkari sesuatu (ad-Dahdah, 1993:449) bukan larangan dalam arti memerintahkan untuk meninggalkan sesuatu. Hal ini terlihat pada contoh (3) setelah huruf la terdapat verba imperfek fi'l mudāri" yaitu يعملون ya'malūna 'mereka mengerjakan'. Pada verba لا يعملون là ya'malūna yang mempunyai arti 'mereka tidak mengerjakan' adalah sebuah pengingkaran dari verba sebelumnya yaitu يعملون ya'malūna yang mempunyai arti 'mereka mengerjakan. Berdasarkan analisis di atas, tidak diragukan kembali bahwa contoh (3) termasuk kalimat deklaratif yang hanya menyatakan sesuatu dan masuk dalama kriteria tindak tutur lokusi.

Contoh (4)

نفس كلبيّة. فهذه نفس مستحوذة وهذه نفس خطيفة
'Nafsu anjing. Ini adalah nafsu yang mengalahkan. Ini adalah nafsu yang merenggut (menerkam)' (Ruslan, 2008: 4).

Contoh (4) termasuk tindak tutur lokusi. Hal ini terlihat dari susunan contoh (4) tersebut yang hanya menyatakan sesuatu. Penutur (khatīb) menyatakan tentang sifat dari nafsu anjing yaitu nafsu yang mengalahkan dan menerkam. Nafsu anjing termasuk nafsu kebinatangan. Nafsu kebinatangan yaitu selalu ingin memenuhi keinginan perut dan syahwat kelamin (al-Jauziyah, 2005: 96). Contoh (4) termasuk bagian isi khotbah pertama yang dituturkan oleh penutur (khatîib) kepada mitra tutur (jama'ah). Jika kita lihat lebih dalam, kalimat di atas hanya mengandung pernyataan dari penutur (khatīib) kepada mitra tutur. Contoh (4) termasuk kalimat deklaratif. Dalam contoh (4) tidak terdapat verba imperatif, verba interogatif, maupun verba imperfek. Sehingga, contoh (4) memenuhi kriteria untuk menjadi tindak tutur lokusi.

\section{Contoh (5)}

$$
\text { كعروف يبدأ من حيث لا يظنّ المرء الدلالة على الخير }
$$

'Memulai kebaikan yaitu dari seseorang tidak berprasangka yang menunjukkan atas kebaikan perbuatannya' (Ruslan, 2008: 6).

Contoh (5) jika diucapkan oleh penutur (khatîb) kepada mitra tutur (jama'ah) maka termasuk tindak tutur lokusi. Tindak tutur lokusi dalam contoh (5) tersebut dapat dilihat dari kandungan kalimat dari penutur (khatīib) kepada mitra tutur (jama'ah) yaitu sebuah pernyataan. Pernyataan dari penutur (khatīib) berisi tentang kebaikan dimulai dari tidak berprasangka buruk kepada orang lain Dalam surat al-Hujarat ayat 12, Allah juga menjelaskan kepada manusia untuk menjauhi banyak prasangka, karena sebagian dari prasangka itu dosa. Contoh (5) termasuk jumlah ismiyah. Mubtada' 
'subjek' dalam contoh (5) yaitu معروف ma'rūf 'kebaikan', sedangkan khabar 'predikat' nya yaitu

يبدأ من حيث لا يظنّ المرء الدالة على الخير كفعله yabdau min haisisu la yazunnu al-maru addalālatu 'alā al-khairi ka fí 'lihi 'seseorang memulai dari tidak berprasangka yang menunjukkan atas perbuatan kebaikannya'. Adapun harf 'huruf'y la 'tidak' yang terdapat dalam contoh (5) dalam bahasa Arab termasuk fi'l manfiy (negative verb) 'verba peniadaan'. Verba peniadaan maksudnya kata kerja yang meniadakan atau mengingkari sesuatu bukan larangan dalam arti memerintahkan untuk meninggalkan sesuatu. Pada contoh (5) tersebut tidak ada informasi untuk mempengaruhi, tetapi informasi tersebut hanya sebuah pernyataan sehingga dapat digolongkan menjadi tindak tut ur lokusi.

Contoh (6)

$$
\text { إبتسامك في وجه أخيك صدقة }
$$

'Tersenyummu kepada saudaramu adalah sedekah' (Ruslan, 2008:11).

Contoh (6) di atas termasuk isi khotbah ke dua yang disampaikan oleh Syeikh Sa îd Ruslan di masjid Syarqī, Kairo Mesir. Penutur (khatīib) pada contoh (6) memberikan informasi kepada mitra tutur (jama'ah) tentang bagaimana keutamaan tersenyum kepada saudara. Pada kasus lain, dalam bagian isi khotbah Jumat pertama, penutur (khatīb) juga mengutip hadis Nabi yang berkenaan dengan tersenyum kepada saudara adalah sedekah. Tuturan seperti contoh (6) adalah sebuah pernyataan atau informasi dari penutur kepada mitra tutur, dengan kata lain dapat disebut dengan kalimat deklaratif. Berdasarkan analisis tersebut, tuturan seperti contoh (6) dapat digolongkan sebagai tindak tutur lokusi.

Contoh (7)

$$
\text { عنس خنزيّة هي الحدرما تكون تتبع الطيبات وتقبل }
$$

'Nafsu babi adalah sangat keruh/suram, mengikuti kebaikan dan menerima kejelekan'(Ruslan, 2008:5).

Contoh (7) adalah bagian dari isi khotbah pertama yang disampaikan penutur (khatīib) kepada mitra tutur (jama'ah). Contoh (7) penutur (khatīib) menyatakan kepada mitra tutur bahwa nafsu babi adalah nafsu yang menjadi suram karena mengikuti kebaikan dan menerima kejelekan. Nafsu babi termasuk nafsu kebinatangan. Nafsu kebinatangan yaitu selalu ingin memenuhi keinginan perut dan syahwat kelamin (al-Jauziyah, 2005: 96). Pernyataan penutur (khatīib) kepada mitra tutur pada contoh (7) tersebut dapat kita golongkan menjadi tindak tutur lokusi. Sesuai dengan teori Searle (1969) menyebut tindak tutur lokusi ini dengan istilah preposisi (Inggris: prepositional act) karena tindak tutur ini hanya berkaitan dengan makna, maka pada contoh (7) tersebut termasuk kalimat yang bermakna dan dapat dipahami oleh mitra tutur, tetapi tidak memberikan pengaruh kepada mitra tutur (jama'ah) untuk bertindak seperti yang diinginkan penutur (khatīib). Selain itu, untuk menegaskan bahwa contoh (7) termasuk tindak tutur lokusi, yaitu adanya kopula. Kopula adalah verba yang menghubungkan subjek dengan komplemen (Kridalaksana, 1983:94). Kopula dalam bahasa Arab disebut dengan fi 'l räbit. yaitu verba untuk mengikat (al-Khuli, 1982: 60). 'Mengikat' dalam hal ini maksudnya mengikat kalimat setelah kopula. Kopula dalam contoh (7) yaitu adanya kata هي hiya. Hiya pada contoh (7) artinya bukan 'dia (perempuan)' akan tetapi, lebih tepat artinya 'adalah'. Contoh (7) menggunakan kata هي hiya bukan ه ه owa, karena menyesuaikan dengan klausa sebelumnya yaitu berjenis femina. Pada contoh (7) dengan adanya kopula tersebut, terlihat 
bahwa kalimat setelah هي hiya 'adalah', masih terikat dengan kalimat sebelumnya. Penutur (khatīb) pada contoh (7) memberi pernyataan tentang nafsu babi yaitu nafsu yang menjadi suram karena mengikuti kebaikan dan menerima kejelekan. Sehingga contoh (7) berpotensi menjadi tindak tutur lokusi.

Contoh (8)

$$
\begin{aligned}
& \text { فككلُ ما يحُُبُهُ الله ويرضى من الأعمال والأحوال الظَّاهرة } \\
& \text { والباطنة هوالعبادة } \\
& \text { في دين الإسلام العظيم }
\end{aligned}
$$

'Segala sesuatu yang dicintai Allah dan diridhai-Nya dari perbuatan-perbuatan serta hal-hal yang nampak dan tidak nampak disebut ibadah dalam agama Islam yang agung.'(Ruslan, 2008:10).

Contoh (8) adalah bagian dari isi khotbah kedua yang disampaikan penutur (khatīb) kepada mitra tutur (jama'ah). Contoh (8) merupakan contoh kalimat yang bermakna dan dapat dipahami oleh mitra tutur. Penutur (khatīib) pada contoh (8) menyatakan tentang definisi ibadah dalam agama Islam. Ibadah menurut penutur (khatīib) yaitu segala sesuatu yang diridhai dan dicintai Allah baik yang tampak maupun tidak nampak. Pernyataan tentang definisi ibadah oleh penutur (khatib) tersebut mengandung makna dan dapat dipahami oleh mitra tutur. Contoh (8) dalam bahasa Arab termasuk jumlah ismiyah. Mubtada pada contoh (8) yaitu فكلُّ ما يحجُهُ الله ويرضى من الاعمال والأحوال الظًّاهرة والباطنة fakullu mā yuhibbuhu Allāhu wa yarḍ̄a min al- a'māli wa al-ạ̣wāli azzāhirati wa al-batinatì 'Segala sesuatu yang dicintai Allah dan diridhai-Nya dari perbuatan-perbuatan serta hal-hal yang nampak dan tidak nampak'. Sedangkan, khabar pada contoh (8) yaitu العبادة في دين al-ibādah fi dini al-Islāmi alAzimi 'ibadah di dalam agama Islam yang agung'. Pada contoh (8) juga terdapat kopula, yaitu kata s huwa. Kata os huwa pada contoh (8) bukan memiliki arti'dia laki-laki', tetapi mempunyai arti yang tepat yaitu 'adalah'. Kopula pada contoh (8) memakai kata هو هي hiya, bukan karena disesuaikan dengan keterangan kalimat sebelumnya yaitu berjenis maskula. Contoh (8) juga termasuk kalimat deklaratif. Kedeklaratifan tersebut terlihat karena tidak adanya unsur perintah, larangan maupun penguatan. Berdasarkan analisis yang sudah dipaparkan, contoh (9) dapat digolongkan menjadi tindak lokusi, karena kalimat tersebut sekedar memberikan pernyataan, tetapi tidak mengandung mempengaruhi mitra tutur (jama'ah) untuk melakukan sesuatu seperti yang diinginkan penutur (khatīib).

\section{Contoh (9)}

$$
\begin{aligned}
& \text { فحقيقة المسلم الّذى استسنمَا لله ربّ العالمينَ بالتّوحيد }
\end{aligned}
$$

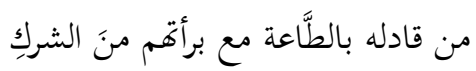

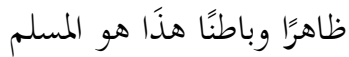

'Hakekat muslim yang meninggikan Allah Tuhan seluruh alam dengan keimanan. Barang siapa yang menuntun kepada-Nya dengan ketaatan yang bebas dari syirik baik yang nampak ataupun tidak dialah Muslim.'(Ruslan, 2008:14).

Contoh (9) merupakan bagian dari isi khotbah kedua dari khotbah Jumat. Contoh (9) termasuk kalimat deklaratif yaitu kalimat yang memberitakan sesuatu. Contoh (9) diutarakan oleh penuturnya semata-mata untuk menyatakan atau menginformasikan sesuatu. Informasi yang diutarakan adalah siapakah yang disebut muslim itu. Pada contoh (9) terdapat kopula, yaitu kata \& huwa Kopula yang berupa kata \& huwa dalam contoh (9) digunakan oleh penutur (khatīib). untuk menjelaskan hakekat orang muslim yaitu seseorang yang menuntun/ membawa kepada Allah sebuah ketaatan yang bebas 
dari syirik lahir maupun batin. Berdasarkan analisis tersebut dapat dikatakan bahwa contoh (10) termasuk tindak tutur lokusi, karena sesuai dengan konsep lokusi yang dikemukakan oleh Searle dalam bukunya Speech Acts: An Essay in The Philosophy of Language (1969, 23-24). Dalam buku tersebut, Searle mengemukakan lokusi adalah tindak tutur untuk menyatakan sesuatu.

Contoh (10)

$$
\text { كلّ كافِرٍ ومسلمٍ هو لله العبد }
$$

'Semua orang kafir dan muslim adalah hamba Allah SWT (Ruslan, 2008:11).

Contoh (10) merupakan bagian isi khotbah pertama. Pada contoh (10) penutur (khatīb) menyatakan bahwa semua orang kafir dan muslim adalah hamba Allah. Informasi yang didapat mitra tutur (jama'ah) adalah siapa saja yang termasuk hamba Allah. Contoh (10) termasuk kalimat deklaratif atau kalimat berita. Dalam contoh (10) juga terdapat kopula dalam bahasa Arab yaitu kata kata ه huwa. Kata suwa dalam contoh (10) memiliki arti 'adalah', sehingga unsur lokusi yang terdapat pada contoh (10) semakin jelas. Sesuai definisi dari tindak tutur lokusi adalah tindak tutur untuk menyatakan sesuatu (Wijana, 1996:17), maka dari analisis di atas, contoh (10) termasuk tindak tutur lokusi karena penutur (khatīb) hanya menyatakan sesuatu.

\subsection{Tindak Ilokusi}

Tindak ilokusi adalah tindak tutur yang berfungsi untuk mengatakan atau menginformasikan sesuatu juga dipergunakan untuk melakukan sesuatu (Wijana, 1996:18). Dengan kata lain, tindak ilokusi adalah apa yang ingin dicapai oleh penuturnya pada waktu menuturkan sesuatu. Tindak tutur ilokusi ini biasanya diidentifikasi dengan kalimat performatif yang eksplisit (Chaer, A dan Leoni, 2004:53). Kalau tindak lokusi hanya berkaitan dengan makna, maka tindak tutur ilokusi ini berkaitan dengan nilai, yang dibawakan oleh preposisinya (Chaer, A dan Leoni, 2004:53). Tindak ilokusi ditampilkan melalui penekanan komunikatif suatu tuturan. Tindak tutur ilokusi ini merupakan bagian sentral untuk memahami tindak tutur (Wijana, 1996:19).

Tindak ilokusi pada khotbah Jumat yang disampaikan oleh Syeikh Sa'id Ruslan di masjid Syarqi, Kairo, Mesir dikelompokkan menjadi lima bagian, yaitu asertif, direktif, ekspresif, komisif, dan deklarasi.

\subsubsection{Asertif}

Tindak tutur Asertif adalah tindak tutur yang mengikat pelakunya kepada kebenaran yang diucapkan. Misalnya: menguatkan, menegaskan, menduga, meramalkan, memprediksi, mengumumkan, mendesak, menunjukkan.

Contoh (11)<smiles>[AlH2]CC[AsH2]</smiles>

يقبل عند الله تبارك وتعالى إلاّ إذا كان خالصا وصوابا

'Amal tidak diterima di sisi Allah kecuali (amal tersebut) ikhlas dan benar' (Ruslan, 2008: 1).

Contoh (11) di atas termasuk tindak lokusi sekaligus tindak ilokusi. Tindak lokusi dari contoh (11) tersebut adalah penutur (khatib) memberikan informasi kepada mitra tutur (jama'ah) tentang amal yang diterima Allah. Adapun tindak ilokusinya yaitu contoh (11) tersebut berisi tentang penegasan atau menegaskan. Hal ini terlihat adanya kata إ illā 'kecuali'. Kata illa 'kecuali' dalam bahasa Arab mempunyai faedah, yaitu mengkhususkan sesuatu setelah sebelumnya adalah pernyataan umum. Dalam contoh (11) tersebut, khatib menegaskan bahwa semua amal perbuatan manusia tidak diterima Allah kecuali yang 
ikhlas dan benar, dengan kata lain semua amal perbuatan yang diterima Allah adalah amal yang ikhlas dan benar. AlGazali menjelaskan bahwa, keikhlasan itu mempunyai hakikat, dasar, dan kesempurnaan. Ini merupakan tiga pilar. Hakikat ikhlas adalah adanya satu motivasi, lawannya adalah persekutuan, yaitu persekutuan dua motivasi, sehingga setiap hal yang berkembang selalu dicampuri dengan unsur lain. Dengan demikian, hakikat ikhlas adalah menyingkirkan campuran dari yang lain. Dasar ikhlas adalah niat, karena di dalam niat itu terdapat keikhlasan. Adapun kesempurnaan ikhlas adalah kejujuran (alGhazali, 2000:297-306). Berdasakan penjelasan di atas, dapat kita ketahui bahwa contoh (11) tersebut mengandung sebuah penegasan dan kalimat tersebut termasuk bentuk tindak tutur asertif.

Contoh (12)

...... أنّ الإنسان إذا أشرك بربه حبط عمله ولم يقبله الله

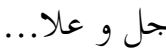

'Sesunggunya apabila manusia menyekutukan Rabbnya, maka hilanglah amalnya dan tidak diterima Allah yang agung dan tinggi' (Ruslan, 2008: 2).

Contoh (13)

$$
\text { إنّ الله طيّب لا يقبل من العمل إلاّ ماكان طيّباً }
$$

'Sesungguhnya Allah itu baik, tidak menerima amal (perbuatan) kecuali perbuatan itu baik'( Ruslan, 2008: 3).

Pada contoh (12) di atas dituturkan penutur (khatib) kepada mitra tutur (jama'ah). Contoh kalimat tersebut termasuk tindak ilokusi. Hal ini terlihat dengan adanya kata أنّ yang artinya 'sesungguhnya'. Huruf anna (أنّ) dalam bahasa Arab faedahnya untuk menguatkan. Pada contoh (12) terdapat huruf ل lam 'tidak', yang dalam bahasa Arab termasuk harf nafyi (letter of negation) 'huruf peniadaan'. Huruf peniadaan maksudnya huruf yang digunakan untuk meniadakan atau mengingkari sesuatu bukan larangan dalam arti memerintahkan untuk meninggalkan sesuatu. Selain itu, kebenaran penutur juga terdapat dalam contoh (12). Kebenaran tersebut dapat dibuktikan dengan kalimat selanjutnya, yaitu penutur menyamakan kalimat tersebut dengan sebuah perkataan (hadis) Nabi yang menyatakan bahwa barang siapa yang mati karena menegakkan agama Allah maka dikatakan mati di jalan Allah. Kandungan hadis tersebut bahwa seseorang yang mati bukan karena Allah (syirik) maka amalnya tidak diterima.

Tindak tutur ilokusi juga terkandung dalam contoh (13). Penutur pada contoh (13) memberikan informasi kepada mitra tutur bahwa Allah itu baik dan hanya menerima amalan yang baik pula. Aspek ilokusi yang dapat kita lihat dalam contoh (13) yaitu juga menggunakan kata إن inna yang artinya 'sesungguhnya'. Selain itu, juga menggunakan kata Kata 'kecuali' dalam bahasa Arab mempunyai faedah yaitu mengkhususkan sesuatu setelah sebelumnya adalah pernyataan umum. Adapun harf 'huruf' V $\overline{l a}^{-}$'tidak' yang terdapat dalam contoh (13) dalam bahasa Arab termasuk fi' manfiy (negative verb) 'verba peniadaan'. Verba peniadaan maksudnya kata kerja yang meniadakan atau mengingkari sesuatu bukan larangan dalam arti memerintahkan untuk meninggalkan sesuatu. Hal ini terlihat dari makna penggalan susunan contoh (13)

لا يقبل lā yuqbalu yang mempunyai makna 'tidak menerima', bukan bermakna 'jangan menerima'. Makna 'tidak menerima' berarti mengingkari makna 'menerima'. Aspek ilokusi lain yang dapat kita cermati, yaitu penutur (khatīib) setelah menuturkan kalimat tersebut juga menuturkan perkataan Nabi (hadis Nabi) yang mendukung pernyataan penutur (khatīib) tersebut. Hal ini adalah sebuah kebenaran yang berdasarkan hadis Nabi 
yang penutur tuturkan. Contoh (13) tersebut jelas termasuk tindak ilokusi asertif karena terdapat unsur penegasan serta penguatan juga unsur kebenaran dari penutur.

Contoh (14)

$$
\text { إنّ المسلم لا ينجس حيا ولا ميّتا }
$$

'Sesungguhnya orang muslim tidak najis hidup dan tidak pula matinya' (Ruslan, 2008:6).

Contoh (14) termasuk bagian dari isi khotbah pertama yang dituturkan penutur (khatīb) kepada mitra tutur (jama'ah). Penutur pada contoh (14) memberikan informasi kepada mitra tutur (jama'ah) bahwa orang muslim tidak najis hidup dan matinya. Contoh (14) tersebut juga mengandung kebenaran dari penutur (khatīib). Hal ini terlihat dari susunan kata yang membentuk kalimat pada contoh (14) tersebut. Pada contoh (14) terdapat kata inna 'sesungguhnya'. Dalam bahasa Arab, kata inna, termasuk / adat at taukid 'kata penegas'. Contoh (14) tersebut mengandung unsur penegas sehingga kebenaran dari penutur (khatib) tidak diragukan kembali, sehingga contoh (14) dapat digolongkan termasuk tindak tutur ilokusi asertif.

\subsubsection{Direktif}

Tindak tutur direktif adalah ujaran yang dilakukan penuturnya dengan maksud agar pendengar melakukan apa yang disebut dalam ungkapan itu, Misalnya: memesan, memerintah, melarang, memohon, menuntut dan memberi nasehat.

Contoh (15)

$$
\text { لا ت تحقرنّ من المعروف شيئا }
$$

'Janganlah kalian memandang rendah suatu kebaikan’ (Ruslan, 2008: 7).
Contoh (15) di atas termasuk isi khotbah Jumat pertama yang dituturkan penutur (khatīb) kepada mitra tutur (jama'ah) yang berfungsi tidak hanya menyatakan suatu larangan, tetapi juga berharap mitra tutur melakukan sesuatu, yaitu meninggalkan perbuatan memandang rendah kebaikan apa pun. Contoh (15) termasuk tindak tutur ilokusi direktif. Hal ini terlihat adanya harf annahyi yang diucapkan oleh penutur (khatîb) kepada mitra tutur (jama'ah). Harf an-nahyi adalah kata yang digunakan untuk larangan dalam arti memerintahkan meninggalkan sesuatu (ad-Dahdah, 1993:262). Harf an-nahyi dalam contoh (15) berupa huruf $y^{\prime} l_{a} \bar{c}$ 'janganlah', kemudian setelah harf an-nahyi diikuti oleh verba imperfek yang menunjukkan kata ganti kamu. Hal ini dapat kita lihat pada contoh (15) terdapat klausa لا تحقرن آَ la tahqiranna yang mempunyai arti 'janganlah kamu memandang rendah'. Penutur (khatīib) menggunakan huruf $\vee l \bar{a}$ tersebut sebagai bentuk larangan, yaitu larangan memandang rendah kebaikan apa pun, bukan sebagai pengingkaran maupun peniadaan. Berdasarkan analisis di atas, contoh (15) termasuk tindak tutur ilokusi direktif.

Contoh (16)

$$
\text { إذا طبخت مرقا فاكثر ماءه وتعاهد جرانك }
$$

'Apabila kamu memasak sayur, maka perbanyaklah kuahnya dan perhatikan tetanggamu' (Ruslan, 2008:7).

Contoh (16) di atas dapat dikatakan ilokusi direktif karena selain menyatakan sesuatu, kalimat tersebut juga mempunyai fungsi lain, yaitu melakukan sesuatu. Pada contoh (16) penutur menyatakan tentang etika memasak sayur dalam Islam, yaitu dengan memperbanyak kuahnya sehingga dapat dibagikan kepada tetangga. Adapun fungsi contoh (16) untuk melakukan sesuatu, yaitu penutur menggunakan kata 
kerja perintah fi'l amr. Hal ini dapat dilihat dari konteksnya, penutur (khatīb) menggunakan fi'l amr أكثر aksirir 'perbanyaklah', dan ta'āhad 'perhatikanlah' yang dimaksudkan untuk memerintah. Pada contoh (16) penutur menggunakan fi'l amr أكثر aksir dan ta'āhad yang berasal dari verba perfek $f i^{\prime} l$

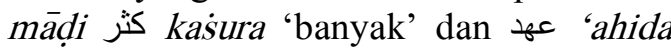
'mengerti'. Penutur (khatīib) pada contoh (16) memerintahkan mitra tutur (jama'ah) untuk memperbanyak airnya. Selain itu, dalam konteks contoh (16) tersebut, penutur juga memerintah mitra tutur untuk memperhatikan tetangganya maksudnya, yaitu dengan membagikan kuah yang diperbanyak tadi, sehingga dengan pemakaian verba perfek oleh penutur (khatîib), diharapkan mitra tutur (jama'ah) melaksanakan apa yang diperintahkan oleh penutur.

\subsubsection{Ekspresif}

Tindak tut ur ekspresif adalah tindak tutur yang dilakukan untuk mengungkapkan atau mengutarakan sikap psikologis penutur terhadap keadaan yang tersirat, misalnya memuji, berterima kasih, mengkritik, mengecam, menuduh. Tindak tutur ilokusi ekspresif cenderung menyenangkan karena itu secara instrinsik ilokusi ini sopan kecuali ilokusi-ilokusi ekspresif seperti mengkritik, mengecam, dan menuduh.

\section{Contoh (17)}

$$
\begin{aligned}
& \text { إنّ الحمد لله نحمده ونستعينه ونستغفره ونعوذ بالله من } \\
& \text { شرور أنفسنا ومن سيئات أعمالنا من } \\
& \text { يهده الله فلا مضل له ومن يضلله فلا هادي له }
\end{aligned}
$$

'Sesungguhnya segala pujian hanya milik Allah, kita memuji-Nya, memohon pertolongan-Nya serta ampunan-Nya. Kita berlindung kepada Allah dari kejahatan diri kita dan dari keburukan amal perbuatan kita. Barang siapa yang diberi petunjuk oleh Allah, maka tidak ada seorang pun yang dapat menyesatkannya, dan barang siapa yang disesatkan-Nya, maka tidak ada yang dapat memberinya petunjuk' (Ruslan, 2008:1).

Contoh (17) di atas termasuk tindak tutur ilokusi ekspresif. Selain untuk menginformasikan sesuatu, kalimat tersebut juga mengandung pujian untuk Allah. Dalam konteks contoh (17) penutur (khatīib) memuji Allah dihadapan mitra tutur (jama'ah) dengan menggunakan kalimat inna al-ḥamdalillāh yang memiliki arti 'sesungguhnya pujian hanya untuk Allah'. Kalimat tersebut diucapkan penutur (khatíib) karena Allah-lah yang mempunyai pertolongan, perlindungan dan ampunan yang luas kepada makhluk-Nya. Selain itu, apabila seseorang diberi petunjuk oleh Allah, maka tidak ada yang bisa menyesatkannya, begitu pula apabila hamba tersebut disesatkan oleh Allah, maka tidak ada yang bisa memberi petunjuk kecuali Allah. Dalam contoh (17) tersebut penutur tidak hanya memuji Allah di hadapan mitra tutur, tetapi juga mengajak mitra tutur untuk memanjatkan pujian untuk Allah. Hal ini terlihat dari struktur kata yang dipakai menggunakan kata نحن nahnu 'kita'. Selain itu, penutur pada contoh (17) juga menggunakan kata inna, yang memiliki arti 'sesungguhnya'. Kata in inna dalam bahasa Arab termasuk adat at-taukid 'kata penegas', sehingga kalimat tersebut mengandung sebuah kebenaran. Kebenaran dalam contoh (17) maksudnya kebenaran tentang pujian itu hanya milik Allah, bukan selain-Nya, sehingga ketika penutur (khatíb) berbicara dengan mitra tutur (jama'ah) dengan menggunakan kata tersebut akan semakin kuat untuk mengajak mitra tutur (jama'ah) untuk memuji Allah.

$$
\begin{aligned}
& \text { Contoh (18) } \\
& \text { محمدا عبده أن لا إله إلاّ الله وحده لا شريك له وأشهد أنّ صلى الله عليه و سلم. }
\end{aligned}
$$


'Aku bersaksi bahwa tidak ada tuhan selain Allah semata, tidak ada sekutu bagiNya. Dan aku bersaksi pula bahwa Muhammad salawat serta keselamatan baginya adalah hamba dan Rasul-Nya'( Ruslan, 2008:1).

Contoh (18) termasuk bagian pembukaan dalam khotbah Jumat. Kalimat tersebut mengandung pujian yang dituturkan penutur (khatīib) untuk Allah dan Rasul-Nya kepada mitra tutur (jama'ah). Pujian dalam contoh (18) yaitu, penutur (khatîib) menyatakan kepada mitra tutur (jama'ah) bahwa tidak ada serikat (sekutu) bagi Allah dan pujian kepada nabi Muhammad, yaitu beliau adalah hamba dan utusan Allah. Hal ini dapat kita cermati, pada contoh (18) penutur menggunakan kata أنّ anna yang memiliki arti 'sesungguhnya' yaitu sebagai penguatan. Selain itu, penutur juga menggunakan kata وحده wahdah yang mempunyai arti 'satu', ditambah dengan kata له là syarikalahu yang mempunyai arti 'tidak ada sekutu' digunakan penutur untuk menerangkan bahwa Allah tidak mempunyai sekutu. Adapun penutur (khatīib) menggunakan kata abdun yang artinya 'hamba' dan kata رسول rasūlu yang mempunyai arti 'utusan' mengandung keterangan bahwa Rasulullah adalah hamba dan utusan-Nya. Berdasarkan analisis di atas, apabila kita cermati, contoh (18) termasuk tindak tutur ilokusi ekspresif, karena adanya unsur pujian untuk Allah dan rasul-Nya, selain itu adanya unsur ajakan kepada mitra tutur (jama'ah) untuk memuji Allah dan RasulNya pula.

\subsubsection{Komisif}

Tindak tutur komisif adalah tindak tutur yang mengikat penuturnya untuk melakukan apa yang disebut dalam ujarannya. Misalnya berjanji, bersumpah, mengancam.

$$
\begin{aligned}
& \text { Contoh (19) } \\
& \text { كما أنّ النبي (ص) قل لمعاذ رضى عنه: يا هُعَاذ ... }
\end{aligned}
$$

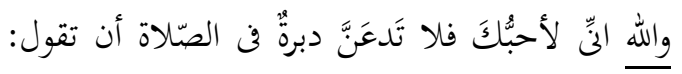

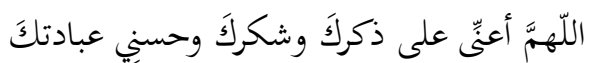

'Sebagaimana bahwa Nabi SAW berkata kepada Muad radiyallāhu 'anhu.

Wahai Mu'āż...demi Allah, sesungguhnya aku benar-benar mencintaimu, maka janganlah kamu mengakhiri/meninggalkan shalat sebelum kamu berdoa' Ya Allah tolonglah aku untuk mengingat-Mu, bersyukur kepada$\mathrm{Mu}$, dan memperbaiki ibadahku untukMu'(Ruslan, 2008:8).

Contoh (19) termasuk bagian isi dari khotbah Jumat pertama. Pada contoh (19) penutur memberikan informasi kepada mitra tutur dengan menyadur perkataan Nabi yaitu untuk berdoa sebelum meninggalkan shalat. Doa tersebut berisi agar Allah menolong hamba-Nya untuk selalu ber $\dot{z} i k r$, bersyukur, dan beribadah kepada-Nya. Pada contoh (19) penutur (khatib) menggunakan kata واله wallāhi yang واله wallāhi dalam bahasa Arab termasuk harf qasam. Harf qasam adalah kata yang digunakan untuk bersumpah dengan tuhan yang agung atau dengan perjanjian yang lain (ad-Dahdah, 1993:254). Selain kata واله wallāhi, harf qasam yang lain dalam bahasa Arab yaitu باله billāhi, ناله tallāhi, dan لَّ lillāhi, yang kesemuanya memiliki arti 'demi Allah'. Berdasarkan analisis di atas, contoh (19) termasuk tindak tutur ilokusi komisif. Hal ini nampak dengan adanya harf qasam berupa kata و wallähi yang digunakan oleh penutur (khatīib) dalam menyampaikan tuturan khotbah jumat. Pada contoh (19) Penutur (khatīib) menyatakan bahwa demi Allah, Rasulullah tidak menyukai Mu'aż apabila meninggalkan salat, tetapi belum berdoa dengan kalimat 


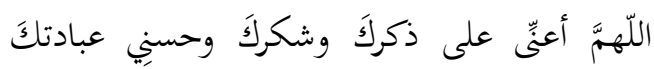
wa Allāhumma a 'innī 'alā żikrika syukrika wa husni ibādatika yang artinya 'Ya Allah tolonglah aku untuk mengingat$\mathrm{Mu}$, bersyukur kepada-Mu, dan memperbaiki ibadahku untuk-Mu.

\subsubsection{Deklarasi}

Tindak tutur deklarasi adalah tindak tutur yang dilakukan penutur dengan maksud untuk menciptakan hal yang baru misalnya, membatalkan, minta maaf, mengundurkan diri, membaptis, memberi nama.

Contoh (20)

$$
\text { أشهد أن لا إله إلاّ الله }
$$

'Aku bersaksi tiada Tuhan kecuali Allah' (Ruslan, 1998:1 dan 10).

Contoh (20) termasuk bagian dalam pembukaan khotbah pertama dan kedua. Pada contoh (20) penutur (khatīib) menggunakan kata أثشر asyhadu yang mempunyai arti 'aku bersaksi'. Verba perfek dari kata أنشه ' شهد Syahada yang mempunyai arti kesaksian. Dari analisis di atas, contoh (20) tersebut merupakan sebuah deklarasi atau persaksian, sehingga contoh (20) dapat dikatakan sebagai tindak tutur ilokusi ekspresif. Hal ini dapat kita cermati dari makna yang terkandung dalam tuturan tersebut, yaitu persaksian bahwa tiada Tuhan selain Allah.

Contoh (21)

$$
\text { أشهد أنّ محمدا عبده ورسوله }
$$

'Aku bersaksi bahwa Muhammad hambaNya dan utusan-Nya' (Ruslan, 2008:1 dan $10)$.

Contoh (21) adalah kalimat yang digunakan penutur (khatīib) di awal khotbah Jumat yang pertama dan di awal khotbah jumat yang kedua. Penutur dalam kalimat tersebut menggunakan kata أشهـ asyhadu 'aku bersaksi', dan huruf أنّ anna yang artinya 'sesungguhnya'. Kata anna (أنّ) dalam bahasa Arab faedahnya untuk menguatkan. Apabila kita cermati makna yang terkandung dalam kata أثشه asyhadu 'aku bersaksi' adalah sebuah deklarasi berupa persaksian. Adapun huruf dipakai oleh penutur untuk menguatkan bahwa dia benar-benar bersaksi. Persaksian di sini yang dimaksud adalah persaksian bahwa Muhammad adalah hamba dan utusan Allah. Berdasarkan analisis tersebut, dapat dikatakan bahwa kalimat itu termasuk tindak tutur ilokusi deklarasi.

\subsection{Tindak Perlokusi}

Tindak perlokusi adalah tindak tutur yang mempunyai daya pengaruh dan efek bagi yang mendengarnya. Tindak tutur ini mempunyai peran menyampaikan informasi dan membawa pengaruh dari tuturan oleh penutur kepada mitra tutur yang mendengar tuturan tersebut. Dengan kata lain, fungsi dari tindak perlokusi yaitu untuk mempengaruhi lawan tuturnya.

Data tuturan khotbah Jumat yang disampaikan oleh Syeikh Sa id Ruslan pada tanggal 25 April 2008 di Masjid Syarqi tepatnya di Propinsi Manufiyah, Desa Subkh Ahad, Markāz Asymūn, Kairo, Mesir, yang menggunakan tindak tutur perlokusi adalah:

Contoh (22)

$$
\text { أقول قولى هذا وأستغقرُ الله العظيمَ لى ولكمُ }
$$

'Saya cukupkan perkataaan saya sampai di sini dan aku memohon ampun kepada Allah yang Agung untukku dan untuk kalian' (Ruslan, 2008:9).

Contoh (22) merupakan bagian yang digunakan oleh penutur (khatib) untuk mengakhiri khotbah pertama. Penutur (khatīb) dari contoh (22) menyampaikan informasi kepada mitra tutur (jama'ah) 
bahwa penutur (khatīi) akan mengakhiri khotbah pertama disertai dengan memohonkan ampun untuk dirinya sendiri dan untuk mitra tutur (khatîib). Namun, jika dilihat dari bentuk tuturannya, dalam konteks tersebut juga mempengaruhi atau memberikan efek bagi mitra tutur. Efek yang ditimbulkan bagi mitra tutur (jama'ah) berbeda-beda. Hal ini dikarenakan mitra tutur (jama'ah nya) bermacam-macam golongan. Salah satu efek bagi mitra tutur (jama'ah) salah satunya yaitu bersiap-siap berdoa antara peralihan khotbah pertama dan kedua. Berdasarkan analisis di atas, dapat diketahui bahwa contoh (22) termasuk dalam tindak tutur perlokusi yang tidak hanya memberikan informasi, tetapi memberikan efek bagi mitra tutur (jama'ah).

\section{Kesimpulan}

Berdasarkan hasil analisis data pada bab sebelumnya, dapat disimpulkan bahwa penutur khotbah Jumat (khatīib) dalam menyampaikan khotbahnya, tidak hanya menggunakan satu macam tindak tutur, tetapi menggunakan beberapa macam tindak tutur, yaitu tindak tutur lokusi, tindak tutur ilokusi dan tindak tutur perlokusi. Adapun tindak tutur yang paling banyak digunakan dalam khotbah jumat oleh penutur asli Mesir dengan judul Baina As-Sürah wa Al-haqiquah 'antara gambar dan kenyataan' adalah tindak tutur lokusi, karena hanya digunakan untuk menyatakan atau menginformasikan sesuatu. Hal ini juga sesuai dengan hakikat khotbah, yaitu wasiat untuk bertakwa kepada khalayak baik bentuknya janji kesenangan maupun ancaman kesengsaraan, sehingga mitra tutur (jama'ah) mendapatkan informasi dari penutur (khatīb) tentang wasiat untuk bertakwa, juga janji kesenangan maupun ancaman kesengsaraan.

Tindak ilokusi dan perlokusi dalam khotbah Jumat tersebut hanya didapatkan beberapa data saja. Adapun tindak ilokusi dalam data khotbah mencakup asertif (menguatkan), direktif (melarang, memerintah), ekspresif (memuji), deklarasi (persaksian), komisif (bersumpah). Dalam khotbah pertama dan kedua, data tindak tutur lokusi ditemukan pada bagian pembukaan, isi, dan penutup, data tindak tutur ilokusi ditemukan pada pembukaan dan isi, sedangkan tindak tutur perlokusi ditemukan pada penutup khotbah Jumat.

\section{Daftar Pustaka}

Abidin, Muhammad Zainal. 2008. Analisis Tindak Tutur dalam Teori Pragmatik Terhadap Amr dalam Al-Qur'an (Studi Tentang Ayat-Ayat Nikah): Analisis Tindak Tutur. S-1 Fakultas Ushuluddin Universitas Islam Negeri Sunan Kalijaga Yogyakarta.

Abu Soleh, Abdul Qudus dan Ahmad Taufik Kalib. 1411 H. al-Balagah wa an-Naqdu. Al-Mamlakatu alArabiyah as-Su'udiyah; Jami'ah alImamu Muhammad bin Su'udiy alIslamiyah.

Al Qur'an dan Terjemahannya. Departemen Agama RI. PT Syamil Cipta Media.

Baal-Baki, R., 1993. Al- Maurid: Qamus 'Araby-Injilizi. Beirut; Darul-'Ilmi Lil-Malayin.

Bin Thahir, Anis bin Ahmad. 2008. Petunjuk Nabi SAW dalam Khutbah Jum'at. Jakarta; Pustaka Imam AsySyafi'i.

Chaer, Abdul, dan Leonie Agustina. 2004. Sosiolinguistik Perkenalan Awal. Jakarta; PT Rineka Cipta.

Ad-Dahdah, Antoin. 1993. Mu'jamu Lughat Annahwu -Al-Arabiyyah. Bairut: Maktabah Lubnan. 
Echols, John. M dan Hasssan Shadily. 1976. Kamus Inggris-Indonesia. Jakarta; PT Gramedia.

Al-Gazhali, Imam. 2000. 40 Prinsip Dasar Agama. Jakarta; Pustaka Amani.

Al-Jauziyah. Ibnu Qayyim. 2005. Mukhtashar Ad-Da' Wa Ad-Dawa'. Solo; Pustaka Arafah.

Al-Khuli, Muhammad Ali. 1992. A Dictionary of Theoretical Linguistic English Arabic Libraries Du Liban.

Kridalaksana, Harimurti. 1983. Kamus Linguistik. Jakarta; Gramedia

2001. Kamus Linguistik. Jakarta; PT. Gramedia.

Leech, Geofrey. 1993. Prinsip-Prinsip Pragmatik. Terjemahan Jakarta; Universitas Indonesia.

Munawwir, Ahmad Warson. 1997. Kamus Arab-Indonesia. Surabaya; Pustaka Progressif.

Al-Mundziri, Imam. 2003. Mukhtasar Sahih Muslim: Ringkasan Hadis Sahih Muslim. Jakarta; Pustaka Amani.

Nababan, P.W.J. 1987. Ilmu Pragmatik. Jakarta; Departemen Pendidikan dan Kebudayaan.
Nadar, F.X. 2009. Pragmatik \& Penelitian Pragmatik. Yogyakarta; Graha Ilmu.

Parker, Frank. 1986. Linguistics for NonLinguist. London; Taylor \& Francis, Ltd.

Ar-Rahbawi, Abdul Qadir. 2008. Fikih Shalat Empat Madzhab. Yogyakarta; Hikam Pustaka.

Sabiq, As, t.t. Fqhus-Sunnah. Jilid I dan II : Jidah; Maktabatul-KhidmatilKhadisah.

Searle, J.R. 1969. Speech Acts. London; Cambridge University Press.

Wijana, I Dewa Putu. 1995. "Wacana Kartun dalam Bahasa Indonesia", Disertasi Doktor Fakultas Pascasarjana Universitas Gadjah Mada. Yogyakarta

Wijana, I Dewa Putu. 1996. Dasar-Dasar Pragmatik. Yogyakarta; Andi Offset

Yule, George. 1996. Pragmatik. Yogyakarta; Pustaka Pelajar.

Az-Zabidi, Imam. 2002. Mukhtasar Sahih al-Bukhari. Ringkasan Hadis Shahih al-Bukhari. Jakarta; Pustaka Amani. 